\title{
HASIL PENELITIAN PELAKSANAAN UNDANG-UNDANG PERKAWINAN DI SULAWESI SELATAN (STUDY TENTANG PERCERAIAN POLIGAMI)

\author{
Kasus Kelurahan Bara-Baraya \\ Kotamadya Ujung Pandang
}

\section{H.M. ALWI NAWAWI}

\section{I}

Undang-undang perkawinan (UU No. 1 Tahun 1974) telah berjalan selama 14 tahun. Hasil yang dicapai dalam proses pelaksanaannya sangat bervariasi. Di satu pihak, ada perkembangan positif yang terjadi dalam masyarakat, sehubungan pelaksanaan UndangUndang tersebut secara konsekuen, tetapi di pihak lain kendala-kendala lain juga muncul berbarengan dengan sukses yang telah dicapai.

Dampak positif dan negatif terjadi hampir diseluruh pelosok tanah air, tanpa kecuali di daerah Tingkat I Sulawesi Selatan. Sulawesi Selatan, terdiri dari 23 Kabupaten (termasuk dua Kotamadya), dengan latar belakang etnik penduduknya yang berbeda-beda. Seperti di daerah lainnya, hasil positif dari penerapan Undang-Undang Perkawinan didaerah ini, seperti semakin timbulnya kesadaran masyrakat terhadap manfaat dan tujuan praktis Undang-Undang tersebut, yang antara lain bermaksud mencegah terjadinya perkawinan yang tidak sesuai dengan prosedur hukum yang berlaku dan makin banyaknya keluarga yang bisa bertahan karena adanya kesadaran secara timbal balik antara suami dan isteri dalam menjalankan fungsi keluarga. Selain dari pada itu, akibat negatifnya juga muncul di berbagai daerah. Perkawinan dibawah tangan (yaitu perkawinan yang diatur ke dalam oleh petugas yang tidak bertanggung jawab tanpa memenuhi ketentuan yang berlaku), perceraian antara suami isteri yang tidak dapat dihindari, dan kendala lainnya terjadi seperti konflik antara tradisi (budaya lokal) dengan ketentuan-ketentuan yang diatur dalam pelaksanaan UndangUndang Perkawinan.

Penelitihan ini dilaksanakan di Kelurahan Bara-baraya Kecamatan Makasar Kotamadya Ujung-Pandang. Maksud diadakannya penelitihan ini, untuk mengevaluasi sejauh mana pelaksanaan Undang-undang Perkawinan berlangsung selama ini. Selain itu penelitihan ini juga bermaksud mempelajari sebab-sebab terjadinya perceraian dan poligami. Bagaimana pandangan masyarakat dalam hal pemilihan jodoh, perkawinan, perceraian, talak, rujuk, poligami dan maskawin. Hal tersebut ditekankan karena berhasil tidaknya tujuan Undang-Undang Perkawinan itu tak dapat dilepaskan dari sistem nilai sosial dan budaya masya-rakatnya.

Penelitihan tentang Undang-Undang Perkawinan ini, walaupun sudah pernah dilaksanakan di beberapa wilayah di Pulau Jawa, tetapi kegiatan ini, diharapkan dapat melengkapi informasi-informasi yang telah ada, terutama pada wilayah-wilayah yang angka perceraiannya semakin meningkat, begitu pula masih banyaknya terjadi poligami sejak adanya 
Undang-Undang Perkawinan.

Penelitihan ini, adalah bagian dari topik yang sama, yang dilaksanakan secara serentak di lima Kabupaten di Sulawesi Selatan, yaitu di Kotamadya Ujung Pandang, Kabupaten Luwu, Kabupaten Bone, Kabupaten Jeneponto dan Kabupaten Enrekang. Di Ujung Pandang, lokasi penelitihan ditetapkan di Kelurahan Bara-baraya Kecamatan Makasar Kotamadya Ujung Pandang.

Kelurahan Bara-baraya ditetapkan secara purfosif dengan beberapa pertimbangan, antara lain karena di kelurahan ini penduduknya berasal dari berbagai latar belakang sosial budaya, mata pencaharian, tingkat pendidikan dan status sosial dalam masyarakat. Penyaringan data dilakukan dengan metode wawancara mendalam, observasi dan study pustaka.

Kecamatan Makasar, salah satu dari sebelas kecamatan yang ada di Kotamadya Ujung Pandang. Luas wilayah $3,12 \mathrm{~km} 2$. Jumlah penduduknya terdiri 100.000 jiwa. Mereka tersebar di lima kelurahan, yaitu Kelurahan Bara-baraya, Kelurahan Lariang Bangi, Kelurahan Macini, Kelurahan Maradekaya, Kelurahan Maricaya. Dari lima kelurahan di Kecamatan Makasar, Kelurahan Bara-baraya termasuk paling padat penduduknya, yaitu sekitar 30.000 jiwa dan tersebar pada sembilan buah RK (Rukun Kampung dan atau Rukun Warga).

Letak geografis daerah ini, terdiri di daerah yang berbatasan dengan Kecamatan Bontoala di sebelah Utara, sebelah Timur berbatasan dengan Kecamatan Tamalate, sebelah Selatan berbatsan dengan Kecamatan Mamajang dan sebelah Barat dengan Kecamatan Ujung Pandang. Daerah ini terletak kurang dari 500 meter dari permukaan laut.

Kelurahan Bara-baraya, sebagai lokasi sampel penelitihan ini luas wilayahnya 71 hektar. Jumlah penduduk rata-rata 380 jiwa perkilometer. Secara keseluruhan, jumlah penduduk di Kelurahan ini mencapai 24.650 jiwa. Penduduk yang tinggal di kelurahan ini berasal dari berbagai latar belakang sosial dan budaya yang berbeda-beda. Mereka berasal dari berbagai etnik di Sulawesi Selatan yang mempunyai tradisi dan pola budaya yang masih dipegang teguh masing-masing etnik. Himpunan etnik ini, seperti dari etnik Enrekang (Massenrengpulu), etnik Tana Toraja, Bugis dan dari etnik asli Makasar.

Identifikasi wilayah yang sangat heterogen inilah yang mendorong penelitihan menetapkan lokasi di kelurahan ini. Variasi etnik yang berbeda, dapat memberikan gambaran persepsi dan responsi masyarakat terhadap pelaksanaan Undang-undang Perkawinan. Hipotesis, bahwa perbedaan latar belakang etnik, kemampuan ekonomi dan tingkat pendidikan akan mempengaruhi sejauhmana persepsi dan pan- dangan masyarakat akan mempengaruhi sejauhmana persepsi dan pandangan masya-rakat sampel terhadap Undang-undang Perkawinan, dapat diuji dalam penelitihan ini, walaupun penelitihan ini masih bersifat eksploratif, tetapi ungkapan yang ditemukan melalui data lapangan memberi gambaran yang sangat menarik bagaimana Undang-Undang Perkawinan dipahami masyarakat, baik secara umum (teks) maupun sampai ketingkat operasionalnya.

Indikator lain yang menjadi dasar pertimbangan pengambilan sampel di daerah ini, karena Kelurahan Bara-baraya terletak di daerah pinggiran kota. Dengan demikian kemungkinan persentuhan antara nilai-nilai tradisional yang berasal dari daerah tetangga dengan nilai-nilai tradisional yang sedang berlangsung di wilayah sampel merupakan suatu kemungkinan yang bisa terjadi. Persen-

No. 1 \& 2 Thn. I Juli / Desember 1990 
tuhan ini, bisa muncul dalam suatu pola budaya yang akomodatif, dan dapat menjadi pola baru dalam menghadapi perkembangan masyarakat yang semakin kompleks.

\section{ni}

Hasil pengumpulan data khususnya yang dilakukan dengan angket menunjukkan bahwa tingkat pengetahuan responden terhadap Undang-undang Perkawinan masih berbedabeda. Dari 47 data responden yang masuk, (jumlah total angket 50 lembar), 42 diantaranya menyatakan pern ah mendengar informasi Undang-undang Perkawinan, dan hanya 5 orang yang mengaku tidak pern ah mendengarkannya. Menjawab pertanyaan tentang apakah responden setuju adanya perkawinan anak perempuan yang berumur 16 tahun kebawah ternyata hanya 1 orang menyatakan setuju, 20 responden tidak setuju, 3 orang tidak tahumenahu tentang permasalahan tersebut, dan 17 responden menyatakan abstein atau tidak memberikan jawaban sama sekali.

Pernyataan yang mengatakan, bahwa menurut UUP laki-laki paling kurang berumur 19 tahn yang dapat melakukan perkawinan, mendapat jawaban, 1 orang setuju sekali. 22 orang setuju, 3 orang menyatakan tidak tahu, dan 14 orang mengatakan tidak setuju. Dari keseluruhan data responden yang masuk, ada tujuh orang yang tidak membcri jawaban sama sekali.

Bagaimana pengetahuan responden tentang Undang-undang Perkawinan, seperti tentang peluang suami atau istcri untuk mengajukan gugatan ke Pengadilan manakala salah seorang di antara mereka melakukan perzinaan, dapat dilihat dari jawaban responden pada angket berikut: 33 orang menjawab, bahwa hak unluk mengajukan gugatan itu bisa, dan pertanyaan pada angket tersebut dianggap salah, 3 orang tidak tahu, dan ragu-ragu 4 orang, serta 1 orang tidak memberikan jawaban.

Responden juga sudah banyak yag mengetahui, bahwa ketentuan dalam Undang-undang Perkawinan, yaitu membolehkan salah satu pihak dari suami atau isteri untuk meminta Pengadilan menceraikan hubungan mereka manakala salah satu diantaranya meninggalkan yang lain selama satu tahun tanpa memberitahukan sama sekali. Pertanyaan seperti ini dijawab responden, sebanyak 35 orang yang mengatakan, bahwa hak untuk minta cerai itu benar, dibenarkan oleh Undang-undang. Hal ini berarti, bahwa pengetahuan responden tentang ketentuan Undang-undang Perkawinan sudah banyak yang tahu dibanding dengan responden yang sama sekali tidak mengetahuinya, yaitu 2 orang. Sedang 6 orang diantaranya memberikan jawaban salah, maksudnya ketentuan untuk menggugat suami atau isteri ke Pengadilan manakala ditinggalkan selama satu tahun, tidak benar.

Pada pernyataan nomor 21 dari kolom pengetahuan responden tentang UndangUndang Perkawinan, khususnya pertanyaan tentang kemungkinan suami atau isteri mengajukan gugatan ke Pengadilan manakala salah satu diantaranya menjalani hukuman penjara selama tiga tahun. Ternyata jawaban responden, 6 orang menyatakan ketentuan itu sesuai dengan Undang-undang, 15 diantaranya menyatakan salah atau tidak sesuai dengan ketentuan, dan 17 orang menyatakan tidak tahu, sedang 8 orang diantaranya bersikap ragu-ragu.

Demikian pula responden memberikan jawaban yang berbeda ketika dimintai tanggapannya tentang kemungkinan suami atau isteri mengajukan gugatan cerai ke Pengadilan manakala salah satu di antaranya menderita sakit sehingga tidak mampu me- 
laksanakan tugas sebagai suami atau isleri. Terhadap pertanyaan ini, ada 20 responden menyatakan hal itu benar, 14 orag menyatakan salah, 5 orang tidak tahu menahu dan 7 orang ragu-ragu, 1 orang lainnya tidak memberikan jawaban. Adapun pernyataan, apakah anak yang dilahirkan harus ikut bapaknya manakala terjadi perceraian menurut ketentuan UndangUndang Perkawinan, maka jawaban responden menyatakan pernyataan itu salah, sebanyak 20 orang, yang menganggap benar sebanyak 11 responden, 6 oang tidak tahu dan 9 orang ragu-ragu. 1 arang diantaranya tidak memberi jawaban.

Pertanyaan yang sangat mendasar, sepcrti apakah seorang suami yang beragama Islam dapat melakukan poligami menurut kemauannya, kapan dan dimana saja, dijawab responden sebagai berikut : 16 orang menyatakan salah, 5 orang menyatakan tidak tahu dan 2 orang ragu-ragu, 1 orang tidak memberikan jawaban sama sekali hasil pcnelitihan tentang bagaimana pandangan masyarakat terhadap Undang-undang Perkawinan, terdiri dari 12 pertanyaan, juga mendapat jawaban yang bervariasi. Pertanyaan tentang pengertian dan contoh suatu pasangan ideal, dijawab responden, bahwa pasangan ideal ialah yang terdiri dari perkawinan antara perawan dengan perjaka. Pernyataan ini dijawab 32 responden mengatakan per-kawinan itu jauh lcbih baik, satu responden mengatakan tidak apa-apa (maksudnya tidak mempunyai kelebihan) dibanding perkawinan antara janda dengan duda. 9 responden malah mengatakan perkawinan seperti itu kurang baik dan 5 responden tidak memberikan jawaban.

Untuk menyelenggarakan suatu perkawinan yang baik, ada bebcrapa pertimbangan yang harus diperhitungkan dalam memilih jodoh. Pada item ini, 3 responden idealnya menyatakan mencari jodoh dengan terlebih dahulu melihat apakah calon pasangan itu punya pekerjaan atau tidak. Mencari jodoh karena pangkat, tidak dijawab oleh responden, tetapi 39 responden mengatakan mancari jodoh, idealnya kalau memperhatikan terlebih dahulu agamanya. Maksudnya apakah orang yang hendak dikawini itu beragama atau tidak, atau apakah sama agamanya dengan orang yang hendak dinikahinya atau tidak. Hanya satu responden mengatakan karena turunan.

Pertanyaan yang mengatakan apakah perceraian itu merupakan hal yang baik atau sebaliknya, dijawab responden sebagai berikut ; 5 orang mengatakan biasa-biasa, 37 orang mengatakan buruk, dan selebihnya tidak memberikan jawaban. Mengenai perceraian, ada 1 responden menyatakan, bahwa perceraian itu ada pengaruhnya, 40 orang menyatakan berpengaruh jelek, dan 3 orang memberikan alasan lain, satu orang tidak memberikan jawaban apa-apa.

Kalau perceraian itu terjadi pada diri seseorang, bagaimana perasaan responden terhadap kasus yang dialaminya seperti itu. Pernyataan ini dijawab responden, bahwa perceraian itu baik, tidak mendapatkan jawaban, 9 orang menyatakan biasa, 4 orang merasa malu, dan selebihnya tidak memberi jawaban. Pertanyaan tentang kemungkinan suami bcrlaku adit terhadap isterinya yang yang jumlahnya lebih dari satu ; dijawab responden ; 8 orang menyatakan biasa, 13 orang raguragu, 18 orang menyatakan tidak bisa, dan 7 orang tidak tahu. Satu orang responden tidak memberikan jawaban.

\section{IV}

Secara umum, hasil penelitihan ini menunjukkan bagaimana variasi jawaban responden

No. 1 \& 2 Thn. I Juli / Desember 1990 
tcrhadap pertanyaan yang diajukan, melalui angket. Katagorisasi pertanyaan ini sengaja dibuat sedemikian rupa, sebab dengan data yang masuk, peneliti segera bisa mengidentifikasi persepsi dan pengetahuan masyarakat sampel terhadap pelaksanaan Undang-undang Per-kawinan.

Data yang diungkap ini, masih bersifat sementara, atau sebagian kecil dari data keseluruhan yang berhasil dihimpun dilapangan. Pada dasarnya, dengan deskripsi hasil penelitihan ini menunjukkan betapa banyaknya faktor yang bisa mempengaruhi kualitas tanggapan masyarakat terhadap suatu gagasan yang akan diketengahkan kepada mereka. Rekomendasi penelitihan ini, secara tidak langsung memberi informasi, bahwa untuk menyadarkan masyarakat terhadap gagasangagasan baru, apalagi yang bersifat merubah pola lama ke pola baru, diperlukan ketekunan dan kemampuan mengamati pelbagai aspek yang terkait dan relevan. Undang-undang
Perkawinan di Kelurahan Bar-Baraya telah menunjukkan betapa masih perlunya penyuluhan secara intensif dari pihak pelaksana sehingga hal tersebut benar-benar menjadi bahagian dari kehidupan rutin masyarakat. Walaupun di lapangan, khususnya kasus Kelurahan Bara-Baraya ini, identifikasi responden dapat dipilah-pilah pada status perkawinan, seperti: Belum kawin satu orang, janda 15 orang, sudah kawin 19 orang dan duda 11 orang. Sedangkan responden yang pernah berpoligami cuma satu orang.

Dibanding dari jumlah responden yang telah memberi jawaban yaitu 47 orang, maka jumlah yang pernah kawin, dan sekarang masih dalam status janda atau duda, sebagaimana dikemukakan di atas sangat tinggi. Penelitihan lebih lanjut tentang motivasi yang lebih mcndasar terhadap terjadinya frekuensi permasalahan perkawinan di Kelurahan ini perlu mendapat perhatian yang lebih jauh.

\section{DAFTAR KEPUSTAKAAN}

,UUNo.1Th. 1974(UU.Perkawinan)

Anwar Nasir Tanjung Nasehat Perkawinan No. 81 Desember, Pustaka Sastra, Jakarta.

\author{
Massulada, Drs. Bugis Makassar di \\ kebudayaan, UI, Jakarta. \\ Taman Djaja Tuntutan Perkawinan dan Rumah \\ Tangga Islam, Al - Ma arif, \\ Bandung.
}

